\title{
Phylogenetic Positions of Novel Aerobic, Bacteriochlorophyll $a$-Containing Bacteria and Description of Roseococcus thiosulfatophilus gen. nov., sp. nov., Erythromicrobium ramosum gen. nov., sp. nov., and Erythrobacter litoralis sp. nov.
}

\author{
VLADIMIR YURKOV, ${ }^{1}$ ERKO STACKEBRANDT ${ }^{2}+$ ANDREW HOLMES, ${ }^{2}$ JOHN A. FUERST, ${ }^{2}$ \\ P. HUGENHOLTZ, ${ }^{2}$ JOCHEN GOLECKI, ${ }^{1}$ NASSER GAD'ON,${ }^{1}$ VLADIMIR M. GORLENKO, ${ }^{3}$ \\ ELENA I. KOMPANTSEVA, ${ }^{3}$ AND GERHART DREWS ${ }^{1 *}$
}

Institute of Biology 2, Microbiology, Albert Ludwigs University, 79104 Freiburg, Germany ${ }^{1}$; Centre for Bacterial Diversity and Identification, Department of Microbiology, The University of Queensland, Brisbane, Queensland 4072, Australia $^{2}$; and Institute of Microbiology, Academy of Science, Moscow, Russia ${ }^{3}$

\begin{abstract}
We analyzed the 16S ribosomal DNAs of three obligately aerobic, bacteriochlorophyll $a$-containing bacteria, "Roseococcus thiosulfatophilus," "Erythromicrobium ramosum," and new isolate T4" (T = type strain), which was obtained from a marine cyanobacterial mat. "Roseococcus thiosulfatophilus" is a member of the $\alpha-1$ subclass of the Proteobacteria and is moderately related to Rhodopila globiformis, Thiobacillus acidophilus, and Acidiphilium cryptum (level of sequence similarity, $90 \%$ ). "Erythromicrobium ramosum" and isolate $\mathbf{T 4} 4^{\mathbf{T}}$ are closely related to Erythrobacter longus and Porphyrobacter neustonensis (level of sequence similarity, 95\%). These organisms are members of the $\alpha-4$ subclass of the Proteobacteria. Strain $\mathrm{T4}^{\mathrm{T}}$ is a motile, red or orange bacterium. The major carotenoids are bacteriorubixanthinal and erythroxanthin sulfate. In vivo measurements revealed bacteriochlorophyll absorption maxima at $377,590,800$, and $868 \mathrm{~nm}$. Strain T4 ${ }^{\mathrm{T}}$ grows in the presence of 5 to $96 \%$ salinity and uses glucose, fructose, acetate, pyruvate, glutamate, succinate, and lactate as substrates. On the basis of its distinct phylogenetic position and phenotypic characteristics which are different from those of Erythrobacter longus, we propose that strain $\mathrm{T} 4^{\mathrm{T}}$ should be placed in a new species of the genus Erythrobacter, Erythrobacter litoralis. The descriptions of "Roseococcus thiosulfatophilus" and "Erythromicrobium ramosum" are emended.
\end{abstract}

Bacteriochlorophyll (Bchl) $a$-containing, strictly aerobic bacteria were first isolated by Japanese scientists $(12,27,29)$. Since then these bacteria have been isolated from a variety of habitats $(7,13,28,45-49,51)$. The photochemical activity of the photosynthetic apparatus has been studied in Erythrobacter sp. strain OCh114 (Roseobacter denitrificans) and "Protaminobacter ruber" NR-1 (investigated as Methylobacterium rhodesianum) $(11,38)$ (names in quotation marks are not on the Approved Lists of Bacterial Names or validation lists and hence are without standing in nomenclature). The levels of photosynthetic units in cells of aerobic photosynthetic bacteria are consistently low. Light and high oxygen tensions suppress Bchl synthesis. Therefore, the contribution of light to energy metabolism in these predominantly chemoheterotrophic bacteria seems to be small. Under intermittent illumination the growth rate increases at the beginning of the light period at the expense of photosynthetic reactions $(10,50)$.

Although the obligately aerobic Bchl-containing bacteria are physiologically very different from the anaerobic photosynthetic purple bacteria belonging to the $\alpha, \beta$, and $\gamma$ subclasses of the Proteobacteria, the organization of the photosynthetic apparatus in members of the two groups seems to be similar. The primary structures of the Bchl-binding proteins of the reaction centers and the antenna complexes in the strains that have been analyzed are very similar to the respective structures

\footnotetext{
${ }^{*}$ Corresponding author. Mailing address: Institute für Biologie 2, Mikrobiologie, Schaenzlestrasse 1, D-79104 Freiburg, Germany. Phone: (49) 761-203 2607. Fax: (49) 761-203 2626.

$\dagger$ Present address: DSM-German Collection of Microorganisms and Cell Cultures, D-38124, Braunschweig, Germany.
}

in anoxigenic purple bacteria $(7,17,30,37)$. Aerobic bacteria containing Bchl $b, c, d$, or $g$ or different types of antenna systems or reaction centers have not been detected. The previously described aerobic Bchl $a$-containing bacteria have been associated with members of the $\alpha$-subclass of the Proteobacteria, including marine Erythrobacter and Roseobacter species and the freshwater strains of "Erythromicrobium," "Roseococcus," and Porphyrobacter species, or have been classified as rhizobia or methylotrophic bacteria $(5,7,13,28,39$, $40,49)$. Comparative studies of the sequences of photosynthetic genes and genes for rRNA may help reveal the phylogenetic relationships among the taxa of Bchl-containing bacteria and may help determine the phylogenetic root of the photosynthetic apparatus. In this paper we describe morphological, physiological, and phylogenetic data for three recently isolated strains of aerobic, Bchl $a$-containing bacteria and propose formal descriptions for these organisms.

\section{MATERIALS AND METHODS}

Bacterial strains. The following strains were investigated: strain $\mathrm{T} 4^{\mathrm{T}}$ ( $\mathrm{T}=$ type strain), which was isolated from a marine cyanobacterial mat (51); "Erythromicrobium ramosum" $\mathrm{E5}^{\mathrm{T}}$ (46, 47); and "Roseococcus thiosulfatophilus" $\mathrm{RB3}^{\mathrm{T}}(45,49)$.

Culture media. Strains $\mathrm{RB}^{\mathrm{T}}$ and $\mathrm{E}^{\mathrm{T}}$ were cultivated in Erlenmeyer flasks semiaerobically in the dark at $30^{\circ} \mathrm{C}$ and $\mathrm{pH}$ 7.6 to 7.8 in medium containing (per liter) $1.0 \mathrm{~g}$ of yeast extract (Difco), $1.0 \mathrm{~g}$ of Bacto Peptone (Difco), $1.0 \mathrm{~g}$ of sodium acetate, $0.3 \mathrm{~g}$ of $\mathrm{KCl}, 0.5 \mathrm{~g}$ of $\mathrm{MgSO}_{4} \cdot 7 \mathrm{H}_{2} \mathrm{O}, 0.05 \mathrm{~g}$ of $\mathrm{CaCl}_{2} \cdot 2 \mathrm{H}_{2} \mathrm{O}, 0.3 \mathrm{~g}$ of $\mathrm{NH}_{4} \mathrm{Cl}, 0.3 \mathrm{~g}$ of $\mathrm{K}_{2} \mathrm{HPO}_{4}, 20 \mu \mathrm{g}$ of vitamin $\mathrm{B}_{12}$, and $1 \mathrm{ml}$ of a trace elements solution (4). 
TABLE 1. Physiological properties of Erythrobacter litoralis $\mathrm{T}^{\mathrm{T}}$, Roseococcus thiosulfatophilus $\mathrm{RB}^{\mathrm{T}}$, Erythromicrobium ramosum $\mathrm{E5}^{\mathrm{T}}$, and Erythrobacter longus $\mathrm{OCh}_{101^{a}}$

\begin{tabular}{ccccc}
\hline \multirow{2}{*}{ Characteristic } & Strain & Strain & Strain & Strain \\
& T4 ${ }^{\mathrm{T}}$ & RB3 $^{\mathrm{T}}$ & E5 $^{\mathrm{T}}$ & Och101
\end{tabular}

Utilization of carbon

sources

Glucose

Fructose

Acetate

Pyruvate

Glutamate

Butyrate

Citrate

Malate

Succinate

Lactate

Formate

Methanol

Ethanol

Benzoate

Antibiotic susceptibility

Chloramphenicol

(100 $\mu \mathrm{g} / \mathrm{disc})$

Penicillin (20 U/disc)

Streptomycin (50 $\mu \mathrm{g} / \mathrm{disc})$

Fusidic acid $(0.5 \mu \mathrm{g}$ disc)

Polymyxin B (100

$\mathrm{U} /$ disc)

Hydrolysis of:

Tween 80

Gelatin

Starch

$\mathrm{G}+\mathrm{C}$ content of DNA ( $\mathrm{mol} \%)$

$a_{-}$, substrate not utilized, resistant to antibiotic, or compound not hydrolyzed + , substrate utilized, susceptible to antibiotic, or compound hydrolyzed; NT, not tested.

Strain $\mathrm{T} 4{ }^{\mathrm{T}}$ was cultivated in the same medium containing $1.5 \% \mathrm{NaCl}$

Morphological and physiological tests. Gram staining was performed by using the method of Gregersen (9). The size and shape of cells were determined by phase-contrast and electron microscopy. The motility of cells was determined by observing a 24-h culture grown in liquid medium. The utilization of organic substrates for growth was investigated under aerobic conditions in liquid medium containing (per liter) $0.3 \mathrm{~g}$ of $\mathrm{KCl}$, $0.5 \mathrm{~g}$ of $\mathrm{MgSO}_{4} \cdot 7 \mathrm{H}_{2} \mathrm{O}, 0.05 \mathrm{~g}$ of $\mathrm{CaCl}_{2} \cdot 2 \mathrm{H}_{2} \mathrm{O}, 0.3 \mathrm{~g}$ of $\mathrm{NH}_{4} \mathrm{Cl}, 0.3 \mathrm{~g}$ of $\mathrm{K}_{2} \mathrm{HPO}_{4}, 15.0 \mathrm{~g}$ of $\mathrm{NaCl}, 0.005 \mathrm{~g}$ of yeast extract, $20 \mu \mathrm{g}$ of vitamin $\mathrm{B}_{12}$, and $1 \mathrm{ml}$ of a trace elements solution (4). The organic substrates were added at a concentration of $1.0 \mathrm{~g} \mathrm{liter}^{-1}$ at $\mathrm{pH} 7.6$ to 7.8 . The results were recorded 4 days after inoculation.

Susceptibility to antibiotics was detected on agar plates by using antibiotic discs. The concentrations used are shown in Table 1. Tests for oxidase and catalase activities and for the capacity to hydrolyze starch, gelatin, and Tween 80 were performed by using standard procedures (8).

Reduction of nitrate was tested after 7 days of incubation in liquid medium containing $0.2 \% \mathrm{KNO}_{3}$ by using test kits for nitrate and nitrite (Merck, Darmstadt, Germany). Fixation of
$\mathrm{CO}_{2}$ (autotrophic growth) was investigated on agar plates without organic substrates by using a GasPak system generating a $\mathrm{CO}_{2}-\mathrm{H}_{2}$ atmosphere (without catalyst) and in a liquid medium containing sodium bicarbonate.

The ability to grow anaerobically was tested in completely filled screw-cap test tubes by using the Pfennig-Lippert media for sulfur and nonsulfur purple bacteria (23).

Analytical procedures. (i) Pigments. Bchl and carotenoids were extracted from whole cells with acetone-methanol $(7: 2$, $\mathrm{vol} / \mathrm{vol}$ ). The total amount of Bchl was determined by using the method of Clayton (1). For quantification of carotenoids a molar extinction coefficient of $128.0 \mathrm{~mol} \cdot$ liter $^{-1} \mathrm{~cm}^{-1}$ was used (2). Protein content was measured by the method of Lowry et al. (18).

(ii) DNA analysis. DNAs were extracted and purified by the method of Marmur (19). The guanine-plus-cytosine $(G+C)$ contents of the DNAs were calculated from thermal melting point data (20). Amplification of the gene encoding the $16 \mathrm{~S}$ rRNA and purification of the PCR products were performed as described previously $(24,25)$. The double-stranded PCR products of "Roseococcus thiosulfatophilus" and "Erythromicrobium ramosum" were sequenced by using the method of Dorsch and Stackebrandt (3). The ribosomal DNA (rDNA) of strain $\mathrm{T} 4^{\mathrm{T}}$ was sequenced by the automated method, as described by Rainey and Stackebrandt (25). The sequence analysis was performed by using previously described primers (31).

Data analysis. The $16 \mathrm{~S}$ rDNA regions of "Roseococcus thiosulfatophilus," "Erythromicrobium ramosum," and strain $\mathrm{T}^{\mathrm{T}}$ analyzed were $1,426,1,115$, and 1,114 nucleotides long, respectively. The three sequences, which have been deposited in the EMBL data library, were aligned with the sequences in a data base containing the sequences of small-subunit rRNAs of members of the alpha subclass of the Proteobacteria (21), as well as sequences that were published recently. Regions whose sequences were not determined in one or more of the reference organisms and regions of alignment uncertainty (i.e., positions 1 to 97,502 to 558 , and 898 to 1072 and from position 1199 to the $3^{\prime}$ terminus [Escherichia coli nomenclature]) were omitted from the analysis (mainly the short sequences for Acidiphilium and Thiobacillus strains available). Pairwise evolutionary distances (expressed as the estimated number of changes per 100 nucleotides) were computed from percentages of similarity by using the correction of Jukes and Cantor (15). Phylogenetic trees were generated from the distance matrices by the neighbor-joining method (26). Bootstrap values, based on the results of an analysis of 500 trees at 438 polymorphic sites, were obtained by using the programs of the PHYLIP package (6). Sequence alignment and data comparison were performed by using a SUN SPARC IPC workstation.

Membrane isolation. Cells were harvested at the end of the exponential growth phase with a continuous-flow centrifuge (Padberg, Lahr, Germany), washed with $10 \mathrm{mM}$ Tris- $\mathrm{HCl}$ buffer ( $\mathrm{pH}$ 7.8), and disrupted in a French pressure cell. Unbroken cells and large debris were removed by centrifugation at $12,000 \times g$ for $20 \mathrm{~min}$ in a Sorvall refrigerated centrifuge equipped with a type SS34 rotor.

The supernatant was layered on a discontinuous gradient consisting of $0.6,1.0,1.2$, and $1.5 \mathrm{M}$ sucrose in $10 \mathrm{mM}$ Tris- $\mathrm{HCl}$ buffer ( $\mathrm{pH} 7.8$ ). After centrifugation for $16 \mathrm{~h}$ at $90,000 \times g$ in a Beckman type Ti60 rotor, the membrane fractions were collected, washed in Tris- $\mathrm{HCl}$ buffer, and analyzed.

Carotenoid analysis. Strain $\mathrm{T} 4^{\mathrm{T}}$ cells and membrane fractions were extracted with acetone, and the pigments were transferred into petroleum ether-diethyl ether $(1: 1)$ by partition. The upper phase was analyzed by thin-layer chromatog- 


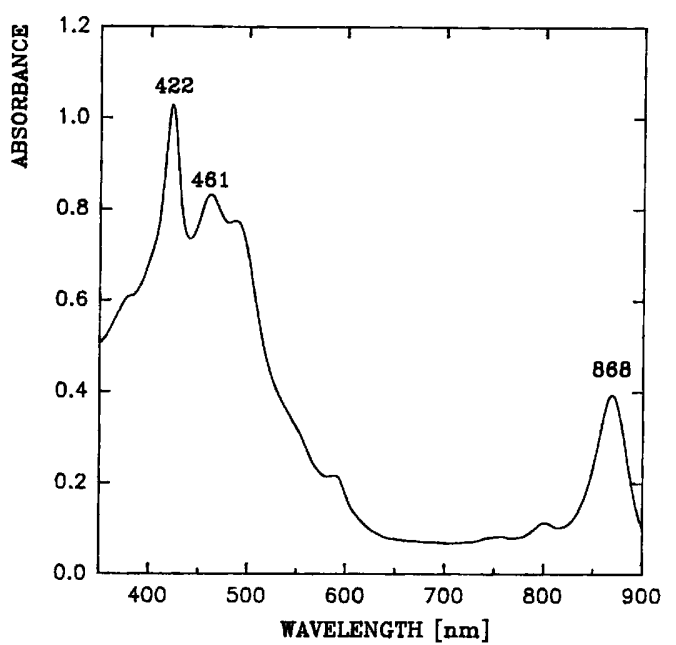

FIG. 1. Absorption spectrum of membrane fraction isolated from cells of Enthrobacter litoralis $\mathrm{T}^{\mathrm{T}}{ }^{\mathrm{T}}$ grown semiaerobically in the dark.

raphy on silica gel, using petroleum ether-diethyl ether-acetone (40:10:10). Single bands of carotenoids were scraped from the plates and compared with previously characterized pigments obtained from "Erythromicrobium ramosum" (44).

Electron microscopy. For electron microscopy the bacteria were embedded in Epon (Roth, Karlsruhe, Germany) after fixation with $1 \%$ glutaraldehyde and then with $1 \%$ osmium tetroxide as described by Kellenberger et al. (16). Preparations were negatively stained with $1 \%$ aqueous uranyl acetate. Micrographs were taken with a Philips model EM 400 electron microscope at $80 \mathrm{kV}$.

Nucleotide sequence accession numbers. The 16S rDNA sequences of "Roseococcus thiosulfatophilus," "Erythromicrobium ramosum," and strain $\mathrm{T} 4{ }^{\mathrm{T}}$ have been deposited in the EMBL data library under accession numbers 72908, 72909, and 72962 , respectively.

\section{RESULTS AND DISCUSSION}

Isolation and description of strain $\mathrm{T}^{\mathrm{T}}$. (i) Habitat and properties. Strain $T 4^{T}$ was isolated from a mature cyanobacterial mat located in the supralitoral zone on the West Frisian island of Texel in The Netherlands. The predominant phototrophic organism resembled oxygenic Microcoleus strains and the anoxygenic purple sulfur bacterium Thiocapsa roseopersicina. Dense populations of colorless sulfur bacteria were also present in the mats. Thiobacillus spp. were observed in the upper layer, and representatives of the genus Thiomicrospira were found in deeper strata (41). Purple nonsulfur bacteria (presumably representatives of the genus Rhodobacter) and marine erythrobacteria (strains $\mathrm{T} 1$ through $\mathrm{T} 7$ ) were also isolated; however, in terms of numbers and biomass, members of the latter two taxa were minority groups (51). This microbial mat is flooded twice a month by the North Sea. Because of heavy rainfall and wind-induced evaporation, the salinity of the pore water may vary from 8 to $10 \%$ to more than $100 \%$.

The morphology and cultural and physiological properties of strain $\mathrm{T} 4{ }^{\mathrm{T}}$ are described below in the description of Erythrobacter litoralis (see also Table 1). This isolate is not capable of anaerobic growth, either in the light or in the dark, on the media used in our experiments or on the Pfennig-Lippert media for nonsulfur and sulfur purple bacteria (23). Vigorous growth was observed when the bacteria were grown in a liquid

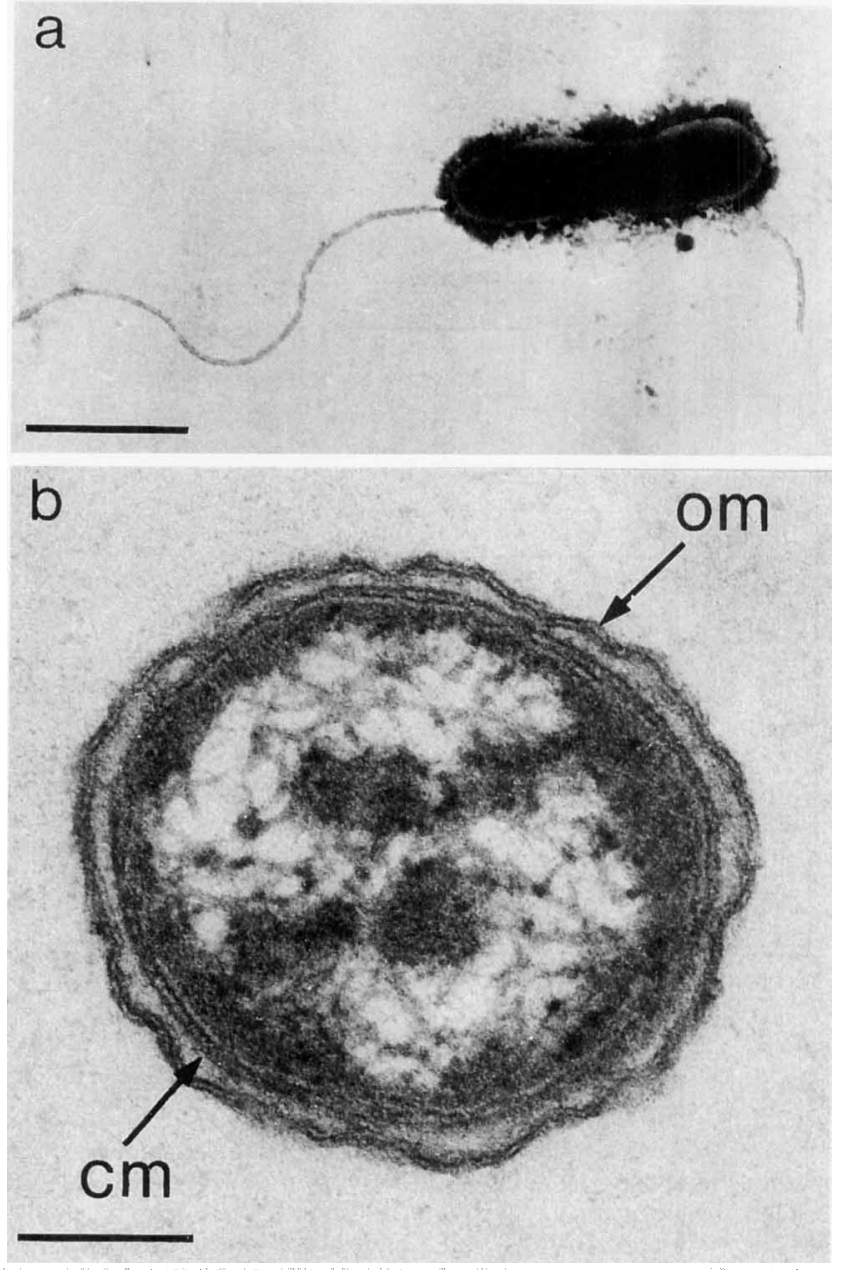

FIG. 2. Erythrobacter litoralis. (a) Negatively stained cell, showing flagellum. Bar $=0.7 \mu \mathrm{m}$. (b) Ultrathin cross section, showing the outer membrane (om) and cytoplasmic membrane $(\mathrm{cm})$. No invaginations of intracytoplasmic membranes were detected. $\mathrm{Bar}=100 \mathrm{~nm}$.

medium on a shaker and in solid medium on the agar surface in the dark or in the light. We did not observe autotrophic growth on mineral media when $\mathrm{CO}_{2}$ and $\mathrm{O}_{2}$ were in the atmosphere.

(ii) Photosynthetic pigments. The in vivo absorption spectra of strain $\mathrm{T}^{\mathrm{T}}$ had major maxima at 377,800 , and $872 \mathrm{~nm}$ (indicating the presence of Bchl $a$ ) and at $461 \mathrm{~nm}$ with broad shoulders around 488 and $437 \mathrm{~nm}$ (indicating the presence of carotenoids). With methanol extracts these peaks shifted to 770 and $368 \mathrm{~nm}$ (Bchl $a$ ) and to 453 and $475 \mathrm{~nm}$ (carotenoids) (51). Membrane fractions purified by sucrose gradient centrifugation produced peaks at 800 and $868 \mathrm{~nm}$, indicating that light-harvesting complex $I$ and the reaction center were present (Fig. 1). The cells had a cytoplasmic membrane (Fig. 2) but no intracytoplasmic membrane when they were grown under semiaerobic conditions in the dark.

Strain $\mathrm{T} 4^{\mathrm{T}}$ produced numerous carotenoids; the carotenoid composition was very similar to that of Erythromicrobium ramosum E5 ${ }^{\mathbf{T}}$ (44) and that of Erythrobacter longus Och101 (34-36). The main carotenoid pigments were bacteriorubixanthinal and very polar erythroxanthin sulfate. Strain $\mathrm{T} 4^{\mathrm{T}}$ cells contained only small amounts of Bchl $a$, but carotenoids were abundant. The Bchl $a$ contents of the cells ranged from 0.9 


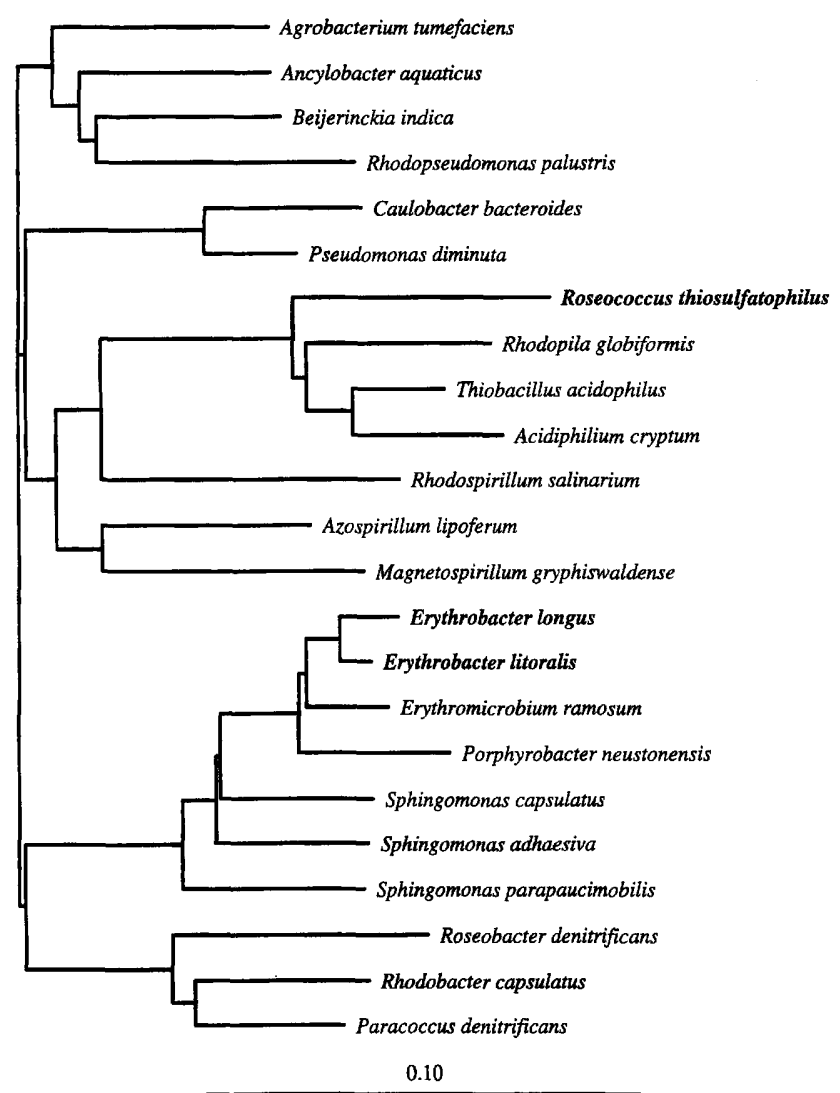

FIG. 3. Phylogenetic positions of representatives of the alpha subclass of the Proteobacteria, as determined by the neighbor-joining method. Scale bar $=10 \%$ difference in nucleotide sequences. The total distance between two organisms is the sum of the horizontal branch lengths. Reference 16S rRNA and DNA data were obtained from the Ribosomal Database Project (21) or are available from us. The numbers are bootstrap values; values less than $50 \%$ were not considered significant and are not shown. The dendrogram was generated by using the algorithm of Saitou and Nei (26), sequence dissimilarity values derived by the algorithm of Jukes and Cantor (15), and the similarity values shown in Table 2 .

$\mathrm{nmol} \cdot \mathrm{mg}$ of protein ${ }^{-1}$ to $3.9 \mathrm{nmol} \cdot \mathrm{mg}$ of $\operatorname{protein}^{-1}$ in the enriched membrane fraction. The ratio of Bchl to carotenoids in the cells was $1: 9$, and the ratio in the membrane fraction was $1: 3.5$.

Strain $\mathrm{T} 4^{\mathrm{T}}$ was susceptible to chloramphenicol, tetracycline, and fusidic acid and was resistant to penicillin, streptomycin, and polymyxin B (Table 1).

Phylogenetic analysis. The organisms investigated in this study were phylogenetically related to members of the $\alpha$ subclass of the Proteobacteria, which also contains the previously described aerobic, Bchl-containing bacteria $(7,33,42)$. "Roseococcus thiosulfatophilus" $\mathrm{RB}^{\mathrm{T}}$ is a member of subclass $\alpha-1$ and is moderately related to Rhodopila globiformis, Thiobacillus acidophilus, and members of the genus Acidiphilium (levels of sequence similarity, $>90 \%$ ) (Fig. 3 and Table 2). Also in this group are two organisms whose sequences were retrieved from a clone library obtained from DNAs that were extracted from an acid forest soil sample (32). Both "Roseococcus thiosulfatophilus" and Rhodopila globiformis contain Bchl $a$ and are able to oxidize thiosulfate $(14,45)$. Both of these species also form pink colonies, and their $\mathrm{G}+\mathrm{C}$ contents are similar (66.3 and $70.4 \mathrm{~mol} \%)$. There are, however, consid- erable differences in the growth conditions which they prefer; Rhodopila globiformis prefers to grow anaerobically under photoheterotrophic conditions, while "Roseococcus thiosulfatophilus" is obligately aerobic. The antenna systems of the two organisms are also different. Rhodophila globiformis seems to have two light-harvesting complexes $(890,862$, and $813 \mathrm{~nm})$ (22), while "Roseococcus thiosulfatophilus" has only one (855 nm) (44).

"Erythromicrobium ramosum" is phylogenetically distantly related to "Roseococcus thiosulfatophilus" (level of sequence similarity, 84.9\%) (Table 2). "Erythromicrobium ramosum" is, however, closely related to Erythrobacter longus (level of sequence similarity, 98\%) (Table 2 and Fig. 2) and strain $\mathrm{T}^{\mathrm{T}}$ (level of sequence similarity, 97.4\%). Together with the recently described taxon Porphyrobacter neustonensis (7), these organisms are members of the $\alpha-4$ subclass of the Proteobacteria. Caulobacter subvibrioides (33) has also been tentatively assigned to this subgroup. The isolated position of this subgroup and its placement close to the branching point of the alpha subclass from the other subclasses of the Proteobacteria have been described previously by Stahl et al. (33) in a study of C. subvibrioides and by Fuerst et al. (7) in a study of the other members of the $\alpha-4$ subgroup.

In a recent publication (43) it was shown that the Sphingomonas group belongs to the $\alpha-4$ subclass of the Proteobacteria and is related to C. subvibrioides (Fig. 3). The Erythromicrobium-Erythrobacter-Porphyrobacter cluster is most closely related to members of the genus Sphingomonas. Erythrobacter longus and strain $\mathrm{T} 4^{\mathrm{T}}$ both contain erythroxanthin sulfate, bacteriorubixanthinal, and other minor components, including $\beta$-carotene, spirilloxanthin, and zeaxanthin. Both species contain only the core antenna complex that absorbs at $870 \mathrm{~nm}$. A similar carotenoid pattern has also been found in "Erythromicrobium ramosum" (34-36, 44). This species, however, contains two light-harvesting complexes, LHI (B870) and LHII (B798832). The high $16 \mathrm{~S}$ rDNA similarity values, similar carotenoid patterns, and similar Bchl-protein complexes of Erythrobacter longus and strain $\mathrm{T} 4^{\mathrm{T}}$ argue against separating these two organisms as members of different genera. Strain $\mathrm{T} 4^{\mathrm{T}}$ grows well at salinity values up to $96 \%$, while Erythrobacter longus grows optimally at salinity values between 17 and 50\%. These two organisms differ in their DNA $\mathrm{G}+\mathrm{C}$ contents, in their substrate utilization patterns, and in their susceptibility to antibiotics. This justifies separation of strain $\mathrm{T} 4{ }^{\mathrm{T}}$ from Erythrobacter longus as new species, for which the name Erythrobacter litoralis is proposed.

"Roseococcus thiosulfatophilus" RB3" and "Erythromicrobium ramosum" $\mathrm{E} 5^{\mathrm{T}}$ have been described recently (45-47). Since these names have not been validated previously and new data have been obtained, more extensive descriptions of these strains are given below.

Description of Roseococcus gen. nov. Roseococcus (Ro.se.o. $\operatorname{coc}^{\prime}$ cus. M. L. adj. roseus, rose, pink; Gr. n. coccus, sphere or spheroidal shape; M.L. masc. n. Roseococcus, pink spherical bacterium). The description of the genus below is based on the original description of Yurkov and Gorlenko (45) and new data. Biochemical, morphological, and 16S rDNA sequence data for strain $\mathrm{RB3}^{\mathrm{T}}\left(=\mathrm{DSM} 8511^{\mathrm{T}}\right)$ support the proposal that a new genus and species should be described.

Cells are gram negative, coccoidal, pink, and motile by means of polarly inserted flagella. Bchl $a$ and carotenoid pigments are present. Cells divide by binary fission. Obligately aerobic, chemoorganotrophic (respiratory metabolism), and facultatively photoheterotrophic. Some members can utilize thiosulfate as an additional energy source. 


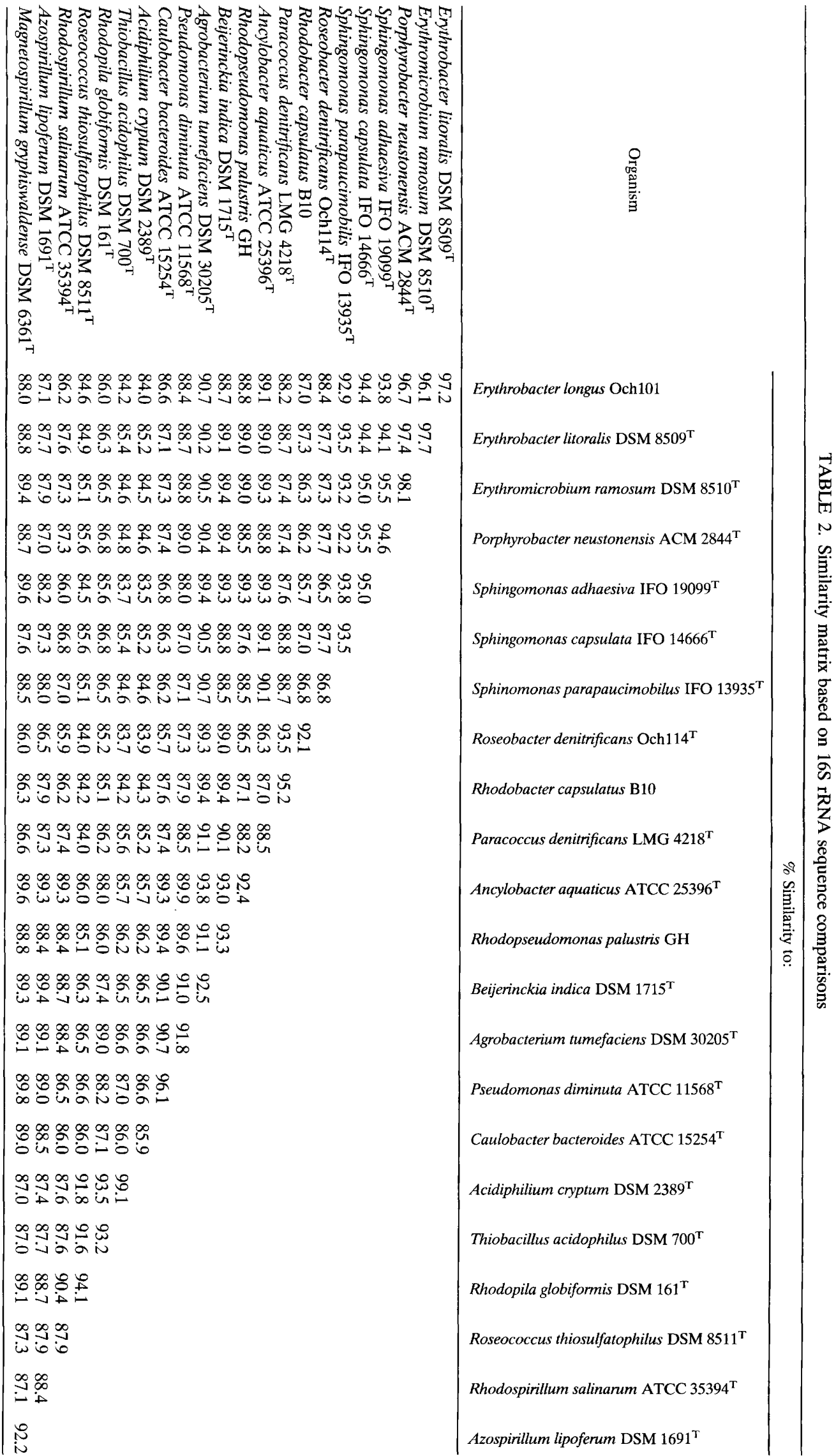


No growth occurs under anaerobic conditions in the light. Methanol is not utilized. $\mathrm{NaCl}$ is not required for growth.

The DNA G+C content is 70.4 mol\% (as determined by thermal denaturation).

Phylogenetically related to members of the $\alpha-1$ subclass of the Proteobacteria.

The type species is Roseococcus thiosulfatophilus.

Description of Roseococcus thiosulfatophilus sp. nov. Roseococcus thiosulfatophilus (thi.o.sul.fa.to'phi.lus. M. L. adj. thiosulfatophilus, thiosulfate liking). The description of the species below is based on the original description of Yurkov and Gorlenko (45) and new data.

Gram-negative, pink cocci that are 0.9 to 1.3 by 1.3 to $1.6 \mu \mathrm{m}$ and are motile by means of single polar flagella. Cells contain Bchl $a$ and carotenoid pigments. Membranes isolated from cells grown semiaerobically in the dark have absorption maxima at 478, 501, and $505 \mathrm{~nm}$ (carotenoids) and at 800 and 855 $\mathrm{nm}(\mathrm{Bchl})$. The major carotenoid is $\mathrm{C}_{30}$ carotenedioate. Aerobic, chemoorganotrophic, and facultatively photoheterotrophic.

Growth occurs on yeast extract and when succinate, acetate, pyruvate, citrate, lactate, malate, or glutamate is used as a sole carbon source; weak growth occurs with glucose, maltose, and glycerol. Fructose, sucrose, ribose, arabinose, butyrate, formate, fumarate, propionate, benzoate, tartrate, methanol, ethanol, mannitol, glycolate, and methanol are not used. Casein is hydrolyzed.

The cells can oxidize thiosulfate to sulfate in the presence of organic compounds. Ribulose diphosphate carboxylase activity is not detected. The cells are susceptible to tetracycline, streptomycin, polymyxin B, erythromycin, amikacin, kanamycin, neomycin, aureomycin, vancomycin, chloramphenicol, and fusidic acid, but resistant to gentamicin, lincomycin, nystatin (Mycostatin), bacitracin, and penicillin. Oxidase and catalase positive.

The storage material consists of polysaccharides, poly- $\beta$ hydroxybutyrate, and polyphosphate.

The $\mathrm{G}+\mathrm{C}$ content of the DNA is $70.4 \mathrm{~mol} \%$.

Habitat: freshwater cyanobacterial mat of a thermal alkaline sulfide spring $\left(54^{\circ} \mathrm{C}\right.$; $\mathrm{pH} 9.3 ; 7.4 \mathrm{mg}$ of sulfide per liter; $1.6 \mathrm{mg}$ of oxygen per liter).

The type strain is RB3 (= DSM 8511).

Description of Erythromicrobium gen. nov. Erythromicrobium (E.ry.thro.mi.cro'bi.um. Gr. adj. erythrus, red; Gr. adj. micros, small; Gr. n. bios, life; N.L. n. Erythromicrobium, red microbe). The description of the genus below is based on the original description of Yurkov et al. (47) and new data. Biochemical, morphological, and 16S rDNA sequence data for strain $\mathrm{E}^{\mathrm{T}}$ (= DSM $8510^{\mathbf{T}}$ ) support the proposal that a new genus and species should be described. Gram negative, rod shaped, and usually motile by means of flagella. Branching may occur. The cells are orange, contain Bchl $a$ and carotenoids, and multiply by binary division.

Aerobic chemoorganotrophs and facultative photoheterotrophs. No growth occurs anaerobically in the light. Ribulose diphosphate carboxylase is not detected. No fermentation and no denitrification activities occur. Phylogenetically related to members of the $\alpha-4$ subclass of the Proteobacteria.

The DNA G+C content ranges from 62.5 to $68.5 \mathrm{~mol} \%$.

The habitat is freshwater. Not halophilic.

On the basis of DNA-DNA hybridization data and phenotypic properties, the following five species have been tentatively identified: "Erythromicrobium sibiricum," "Erythromicrobium ursincola," "Erythromicrobium ezovicum," "Erythromicrobium hydrolyticum," and "Erythromicrobium ramosum" (49). The type species is "Erythromicrobium ramosum.
Description of Erythromicrobium ramosum sp. nov. Erythromicrobium ramosum (ra.mo'sum. L. adj. ramosum, ramifying, referring to the morphology of the cells). Gram-negative, orange rods that are 0.6 to 1.0 by 1.3 to $2.5 \mu \mathrm{m}$. Cells may branch. Multiplication occurs by binary or ternary fission. Motile by means of polar flagella. Bchl $a$ and carotenoids are present. The cytoplasmic membrane contains a reaction center and two light-harvesting complexes, one with an absorption maximum at $870 \mathrm{~nm}$ and one with absorption maxima at 798 and $832 \mathrm{~nm}$. The major carotenoids are the very polar compound erythroxanthin sulfate and bacteriorubixanthinal. Optimal growth occurs at temperatures between 25 and $30^{\circ} \mathrm{C}$ and at $\mathrm{pH}$ values between 7.0 and 8.5 .

The optimum substrates for growth are glucose, sucrose, maltose, acetate, pyruvate, butyrate, malate, succinate, fumarate, propionate, glutamate, casein hydrolysate, and yeast extract. Growth also occurs on fructose, citrate, lactate, tartrate, and ethanol. No growth occurs on ribose, arabinose, formate, benzoate, methanol, mannitol, glycerol, and glycolate. Methanol is not utilized. Starch, gelatin, and Tween 80 are not hydrolyzed. Oxidase and catalase positive. The tricarboxylic acid cycle operates. The glyoxalate shunt has been observed in strain E4 (2), but not in strain $E 5^{\mathrm{T}}$.

Susceptible to the following antibiotics: tetracycline, polymyxin B, erythromycin, nalidixic acid, amikacin, gentamicin, nystatin, bacitracin, kanamycin, neomycin, aureomycin, vancomycin, novobiocin, chloramphenicol, and fusidic acid. Resistant to penicillin, ampicillin, streptomycin, and nystatin. The storage compounds are polysaccharides, poly- $\beta$-hydroxybutyric acid, and polyphosphates.

The $\mathrm{G}+\mathrm{C}$ content of the DNA is 63.6 to $64.2 \mathrm{~mol} \%$.

Habitat: cyanobacterial mat from an alkaline spring ( $\mathrm{pH} 9.5$; $\left.25^{\circ} \mathrm{C}\right)$.

The type strain is E5 (= DSM 8510).

Description of Erythrobacter litoralis sp. nov. Erythrobacter litoralis (li.to.ra'lis. L. adj. litoralis, at the beach or coast, referring to the supralitoral habitat). Gram-negative, rodshaped cells. Short chains up to five cells long may occur. The cells are red or orange, become red or brown in older cultures, and are 1.0 to 1.3 by 0.2 to $0.3 \mu \mathrm{m}$. Motile by means of flagella (Fig. 2). Cells contain Bchl $a$ and carotenoids. The main carotenoids are bacteriorubixanthinal and erythroxanthin sulfate. The in vivo absorption spectrum of Bchl $a$ has maxima at $370,590,800$, and $868 \mathrm{~nm}$. The cells do not form intracytoplasmic membranes. Aerobic, chemoorganotrophic, and catalase and oxidase positive. Growth occurs on glucose, fructose, butyrate, glutamate, acetate, and lactate, and weak growth occurs on succinate. Does not utilize methanol. Tween 80 is hydrolyzed, but gelatin and starch are not hydrolyzed. Nitrate is not reduced. Susceptible to chloramphenicol, tetracycline, and fusidic acid. Resistant to penicillin, streptomycin, and polymyxin B. The optimal temperature for growth is 25 to $30^{\circ} \mathrm{C}$.

Habitat: marine cyanobacterial mat in a supralitoral zone. This organism is able to grow in a very wide salinity range, from $5 \%$ (freshwater) to $96 \%$.

The DNA G+C content is $67 \mathrm{~mol} \%$.

The type strain is T4 (= DSM 8509).

\section{ACKNOWLEDGMENTS}

This work was supported by grants from the Deutsche Forschungsgemeinschaft and the Fonds der Chemischen Industrie and by a scholarship from the Alexander von Humboldt-Stiftung to V.Y. The phylogenetic analysis was supported by grants from the Australian Research Council to J.A.F. and E.S. 
We thank Norbert Windhab for his help with the determination of the $\mathrm{G}+\mathrm{C}$ content of strain $\mathrm{T} 4^{\mathrm{T}}$ DNA.

\section{REFERENCES}

1. Clayton, R. R. 1966. Spectroscopic analysis of bacteriochlorophyll in vivo and in vitro. Photochem. Photobiol. 5:669-677.

2. Davies, B. H. 1965. Analysis of carotenoid pigments, p. 489-532. In T. W. Goodwin (ed.), Chemistry and biochemistry of plant pigments. Academic Press, London.

3. Dorsch, M., and E. Stackebrandt. 1992. Some modifications in the procedure of direct sequencing of PCR amplified 16S rDNA. J. Microbiol. Methods 16:271-279.

4. Drews, G. 1983. Mikrobiologisches Praktikum, p. 11. Springer, Berlin.

5. Evans, E. R., D. E. Fleischman, H. E. Calvert, P. V. Pyati, G. Alter, and N. S. Subba Rao. 1990. Bacteriochlorophyll and photosynthetic reaction centers in Rhizobium strain BTA:1 Appl. Environ. Microbiol. 56:3445-3449.

6. Felsenstein, J. 1988. PHYLIP manual, version 3.2. University Herbarium, University of California, Berkeley.

7. Fuerst, J. A., J. A. Hawkins, A. Holmes, L. I. Sly, C. J. Moore, and E. Stackebrand. 1993. Porphyrobacter neustonnensis gen. nov., sp. nov., an aerobic bacteriochlorophyll-synthesizing budding bacterium from freshwater. Int. J. Syst. Bacteriol, 43:125-134.

8. Gerhardt, P., R. G. E. Murray, R. N. Costilow, E. W. Nester, W. A. Wood, N. R. Krieg, and G. B. Phillips (ed.). 1981. Manual of methods for general bacteriology. American Society for Microbiology, Washington, D.C.

9. Gregersen, T. 1978. Rapid method for distinction of gram-negative from gram-positive bacteria. Eur. J. Appl. Microbiol. Biotechnol. $5: 123-127$.

10. Harashima, K., K. Kawazoe, I. Yoshida, and H. Kamata. 1987 Light-stimulated aerobic growth of Erythrobacter species OCh114. Plant Cell Physiol. 28:365-374.

11. Harashima, K., M. Nakagawa, and N. Murata. 1982. Photochemical activities of bacteriochlorophyll in aerobically grown cells of heterotrophs, Erythrobacter species (OCh114) and Eythrobacter longus (OCh101). Plant Cell Physiol. 23:185-193.

12. Harashima, K., T. Shiba, T. Totsuka, U. Simidu, and N. Toga. 1978. Occurrence of bacteriochlorophyll a in a strain of an aerobic heterotrophic bacterium. Agric. Biol. Chem. 42:16271628.

13. Harashima, K., and K. Takamiya. 1989. Photosynthesis and photosynthetic apparatus, p. 39-72. In K. Harashima, T. Shiba, and N. Murata (ed.), Aerobic photosynthetic bacteria. Japan Scientific Societies Press/Springer Verlag, Tokyo.

14. Imhoff, J. F., and H. G. Trüper. 1989. Purple non-sulfur bacteria, p. 1658-1682. In J. T. Staley, M. P. Bryant, N. Pfennig, and J. G. Holt (ed.), Bergey's manual of systematic bacteriology, vol. 3 . Williams \& Wilkins, Baltimore.

15. Jukes, T. H., and C. R. Cantor. 1969. Evolution of protein molecules, p. 21-132. In H. N. Munro (ed.), Mammalian protein metabolism. Academic Press, New York.

16. Kellenberger, E., A. Ryter, and J. Sechaud. 1958. Electron microscope study of DNA-containing plasms. J. Biophys. Biochem. Cytol. 4:671-678.

17. Liebetanz, R., U. Hornberger, and G. Drews. 1991. Organization of the genes coding for the reaction center $\mathrm{L}$ and $\mathrm{M}$ subunits and B870 antenna polypeptides $\alpha$ and $\beta$ from the aerobic photosynthetic bacterium Erythrobacter spec. OCh114. Mol. Microbiol. 5:1459-1468.

18. Lowry, O. H., N. J. Rosebrough, A. L. Farr, and R. J. Randall. 1951. Protein measurement with the Folin phenol reagent. J. Biol. Chem. 193:265-275.

19. Marmur, J. 1961. A procedure for the isolation of deoxyribonucleic acid from microorganisms. J. Mol. Biol. 3:208-218.

20. Marmur, J., and P. Doty. 1962. Determination of the base composition of deoxyribonucleic acid from its thermal denaturation temperature. J. Mol. Biol. 5:109-118.

21. Olsen, G. J., Overbeek, R. Larsen, N. Marsh, M. J. McCaughey, M. A. Maciukenas, W. M. Kuan, T. J. Macke, and C. R. Woese. 1992. The ribosomal database project. Nucleic Acids Res. 20 (Suppl.):2199-2200.
22. Pfennig, N. 1974. Rhodopseudomonas globiformis spec. nov., a new species of Rhodospirillaceae. Arch. Microbiol. 100:197-206.

23. Pfennig, N., and K. D. Lippert. 1966. Über das Vitamin $B_{12-}$ Bedürfnis phototropher Schwefelbakterien. Arch. Mikrobiol. 55: 245-256.

24. Rainey, F. A., M. Dorsch, H. W. Morgan, and E. Stackebrandt. 1992. 16S rDNA analysis of Spirochaeta thermophila: its phylogenetic position and implications for the systematics of the order Spirochaetales. Syst. Appl. Microbiol. 15:197-202.

25. Rainey, F. A., and E. Stackebrandt. 1993. Phylogenetic analysis of the bacterial genus Thermobacteroides indicates an ancient origin of Thermobacteroides proteolyticus. Lett. Appl. Microbiol. 16:282286.

26. Saitou, N., and M. Nei. 1987. The neighbour-joining method: a new method for reconstructing phylogenetic trees. Mol. Biol. Evol. 4:406-425.

27. Sato, K. 1978. Bacteriochlorophyll formation by facultative methylotrophs, Protaminobacter ruber and Pseudomonas AM1. FEBS Lett. 85:207-210.

28. Shiba, T., Y. Shioi, K. I. Takamiya, D. C. Sutton, and C. R. Wilkinson. 1991. Distribution and physiology of aerobic bacteria containing bacteriochlorophyll $a$ on the east and west coasts of Australia. Appl. Environ. Microbiol. 57:295-300.

29. Shiba, T., V. Simidu, and N. Taga. 1979. Distribution of aerobic bacteria which contain bacteriochlorophyll $a$. Appl. Environ. Microbiol. 38:43-45.

30. Shimada, K., H. Hayashi, and M. Tasumi. 1985. Bacteriochlorophyll-protein complexes of aerobic bacteria, Eryhrobacter longus and Enthrobacter species OCh114. Arch. Microbiol. 143:244-247.

31. Stackebrandt, E., and O. Charfreitag. 1990. Partial 16S rRNA primary structure of five Actinomyces species: phylogenetic implications and development of an Actinomyces israelii specific oligonucleotide probe. J. Gen. Microbiol. 136:37-43.

32. Stackebrandt, E., W. Liesack, and B. M. Goebel. 1993. Bacterial diversity in a soil sample from a subtropical Australian environment as determined by 16S rDNA analysis. FASEB J. 7:232-236.

33. Stahl, D. A., R. Key, B. Fleshner, and J. Smit. 1992. The phylogeny of marine and freshwater caulobacters reflects their habitat. J. Bacteriol. 174:2193-2198.

34. Takaichi, S., K. Furihata, S. I. Ishidsu, and K. Shimada. 1991. Carotenoid sulfates from the aerobic photosynthetic bacterium Erythrobacter longus. Phytochemistry (Oxford) 30:3411-3415.

35. Takaichi, S., K. Shimada, and J. I. Ishidsu. 1988. Monocyclic cross-conjugated carotenal from an aerobic photosynthetic bacterium, Erythrobacter longus. Phytochemistry (Oxford) 27:36053609.

36. Takaichi, S., K. Shimada, and J. I. Ishidsu. 1990. Carotenoids from the aerobic photosynthetic bacterium, Erythrobacter longus: $\beta$-carotene and its hydroxyl derivates. Arch. Microbiol. 153:118122.

37. Takamiya, K., K. Iba, and K. Okamura. 1987. Reaction center complex from an aerobic photosynthetic bacterium, Erythrobacter species OCh114. Biochim. Biophys. Acta 890:127-133.

38. Takamiya, K., and K. Okamura. 1984. Photochemical activities and photosynthetic ATP formation in membrane preparation from a facultative methylotroph, Protaminobacter ruber strain NR-1. Arch. Microbiol. 140:21-26.

39. Trüper, H. G. 1987. Phototrophic bacteria. A taxonomic versus phylogenetic survey. Microbiologia 3:71-89.

40. Urakami, T., and K. Komagata. 1984. Protomonas, a new genus of facultatively methylotrophic bacteria. Int. J. Syst. Bacteriol. 34: 188-201.

41. Visscher, P. T. 1992. Microbial sulfur cycling in laminated marine ecosystems. Ph.D. thesis. University of Groningen, Haaren, The Netherlands.

42. Woese, C. R. 1987. Bacterial evolution. Microbiol. Rev. 51:2211271.

43. Yabuuchi, E., E. Yano, H. Oyaizu, Y. Hashimoto, T. Ezaki, and H. Yamamoto. 1990. Proposals of Sphingomonas paucimobilis gen. nov. and comb. nov., Sphingomonas parapaucimobilis sp. nov., Sphingomonas yanoikuyae sp. nov., Sphingomonas adhaesiva sp. nov., Sphingomonas capsulata comb. nov., and two genospecies of the genus Sphingomonas. Microbiol. Immunol. 34:99-119. 
44. Yurkov, V., N. Gad'on, and G. Drews. 1993. The major part of polar carotenoids of the aerobic bacteria Roseococcus thiosulfatophilus RB3 and Erythromicrobium ramosum E5 is not bound to the bacteriochlorophyll a complexes of the photosynthetic apparatus. Arch. Microbiol. 160:372-376.

45. Yurkov, V., and V. M. Gorlenko. 1992. A new genus of freshwater aerobic, bacteriochlorophyll a-containing bacteria, Roseococcus gen. nov. Microbiology (Engl. Transl. Mikrobiologiya) 60:628-632.

46. Yurkov, V., and V. M. Gorlenko. 1993. New species of aerobic bacteria from the genus Erythromicrobium containing bacteriochlorophyll a. Microbiology (Engl. Transl. Mikrobiologiya) 61: 163-168.

47. Yurkov, V., V. M. Gorlenko, and E. I. Kompantseva. 1992. A new type of freshwater aerobic orange-coloured bacterium, Erythromicrobium gen. nov. containing bacteriochlorophyll a. Microbiology (Engl. Transl. Mikrobiologiya) 61:169-172.
48. Yurkov, V., V. M. Gorlenko, L. L. Mityushina, and D. A. Starynin. 1991. Effect of limiting factors on the structure of phototrophic associations in thermal springs. Microbiology (Engl. Transl. Mikrobiologiya) 60:763-711.

49. Yurkov, V., A. M. Lysenko, and V. M. Gorlenko. 1991. Hybridization analysis of the classification of bacteriochlorophyll a-containing freshwater aerobic bacteria. Microbiology (Engl. Transl. Mikrobiologiya) 60:362-366.

50. Yurkov, V., and H. van Gemerden. 1993. Impact of light/dark regime on growth rate, biomass formation and bacteriochlorophyll synthesis in Erythromicrobium hydrolyticum. Arch. Microbiol. 159: 84-89.

51. Yurkov, V., and H. van Gemerden. 1993. Abundance and salt tolerance of obligately aerobic, phototrophic bacteria in a microbial mat. Neth. J. Sea Res. 31:57-62. 